\title{
Improved Methods of Human Capital Valuation in the Modern Company
}

\author{
Alexei V. Bolshov ${ }^{1}$ \\ ${ }^{1}$ Kazan Federal University, Russian Federation \\ Correspondence: Alexei V. Bolshov, Kremlin str. 18, Kazan, 420008, Russian Federation. E-mail: \\ science-kfu@mail.ru
}

Received: June 20, 2014 Accepted: July 25, 2014 Online Published: September 28, 2014

doi:10.5539/ass.v10n20p80 URL: http://dx.doi.org/10.5539/ass.v10n20p80

\begin{abstract}
The purpose of this study is to develop a mechanism for the effective management of human capital value, in relation to the administrative staff of the modern organization. The paper proposes a method of optimizing the investment in human capital, which includes such components as expenses structuring in the formation and development of human capital, evaluation and orientation dynamics of the risks of the staff life-cycle phases, modelling optimal amount of investment in human capital development, taking into account the different degrees of riskiness, forecasting of return of human capital investment in managing positions and structural units, the development of recommendations for the creation of institutional mechanism to assess and control the cost of human capital. In general, the proposed method allows predicting the cost of human capital in managing positions and structural units, and planning the necessary level of the return of investment and developing measures for their optimization according to model-based estimates of investment in human capital, taking into account the change in the riskiness of the investment. The proposed technique is tested on the real project for the reorganization of the executive office, LLC "Medical Centre" (all names in the article have been changed). It is revealed that human capital of the executive office of organization is underfunded for a long time in terms of technical equipment jobs, funds for financial incentives of employees and the formation of executive stuff' wage supplements. The main risks that affect the value of human capital are: stuff turnover due to lack of career prospects, uncompetitive salary, insufficient technical equipment of working places of managers and specialists. As part of human capital cost management it is proposed: the creation of a special structural unit acting as the valuation of human capital on the basis of recommended optimization models, tracking its dynamics, monitoring of factors influencing the efficiency of human capital, that develop measures to improve the personnel and investment policies of the organization.
\end{abstract}

Keywords: human capital, investment in human capital, the riskiness of human capital, human capital management cost

\section{Introduction}

The most important factor that influences the strategic competitiveness of forming its fundamental value is the quality and efficiency of human capital. The most striking instance of this effect appears in relation to the executive office, of which largely depends on the choice of optimal strategy and tactics of the modern organization. Therefore, the issues of formation and development of human capital, monitoring and management of its cost are becoming more relevant as we move to the information type of post-industrial economy.

For the first time, the term "human capital" and an attempt to evaluate it, was undertaken in the middle of last century, when T. Schultz suggested macroeconomic approach to the assessment and management of human capital development. In 1964 G. Becker substantiated the effectiveness of human capital and made a microeconomic approach to its management. For laying the foundation of human capital theory, T. Schultz was awarded the Nobel Prize in economics in 1979 as well as G. Becker in 1992. In 1976, J. Kendrick proposed cost method of calculating the cost of human capital, based on statistical data on cumulative investment of family and state restoration of human capital. Later, in the 1990s, in the work of J. Mincer (1994) the contribution of education and length of employment in human capital is estimated. C.B. Mulligan and X. Sala-i-Martin (1995) proposed a methodology for assessing the total stock of human capital with the help of indexes. The Experts of World Bank has compiled these and other methods of valuation of human capital in the late 1990s in the method 
of measurement of national welfare.

A new surge of scientific research on this topic came in the beginning of 2000 when the concept of intellectual capital as the basis of the fundamental value of the company began to develop actively. In 1996 A. Brooking examined the impact of human capital on the other structural components of intellectual capital-organizational and client capital. In 1997, M. Kiernan positioned human capital as an important factor in assessing the company's strategic competitiveness. Later, the development of problems of assess the effectiveness of human capital at different times was studied by T. Stewart, L. Edvinsson, J. Roos, J. Hayton, P. Wright, J. Shaw and others.

The solving such problems identified the need for theoretical and practical developments, based on a model of the global economy, particularly adapted to Russian conditions of economic activity.

The authors, mentioned above, at a high theoretical level, considered the issues structuring human capital, the mechanism of its formation and development, offered a variety of methods of valuation of human capital at the micro and macro level, formulated the principles of human capital management. However, insufficient attention is paid to monitoring the functioning of the human capital risk, its assessment in the forecasting process and its cost efficiency.

\section{Methodology}

An important aspect of the mechanism of cost management of human capital is the most adequate and accurate assessment of the optimal value of investments in its operation and development and forecasting economic efficiency. It should be mentioned that the problem of assessing investment in human headband with the specific risks is covered quite fragmented in the literature.

We put forward a technique that synthesizes the cost approach to assess the cumulative investment in managerial position and expert evaluation method riskiness of investing in different stages of the life cycle of the staff. Under this method is suggested to calculate the volume of investments, based on the structure of direct and indirect costs in the managerial personnel, identified lifecycle stage personnel, standard investment risks and expertise specific risks functioning of the human capital. In parallel, we define the efficiency of investment in human capital on the basis of indicators of their perceived profitability that allows you to define the limits of investment in staff and technical equipment, predict their profitability. Calculated investment options allow you to develop an organizational plan of measures to develop human capital. The overall logic of the proposed technique is illustrated in schematic form in Figure 1.

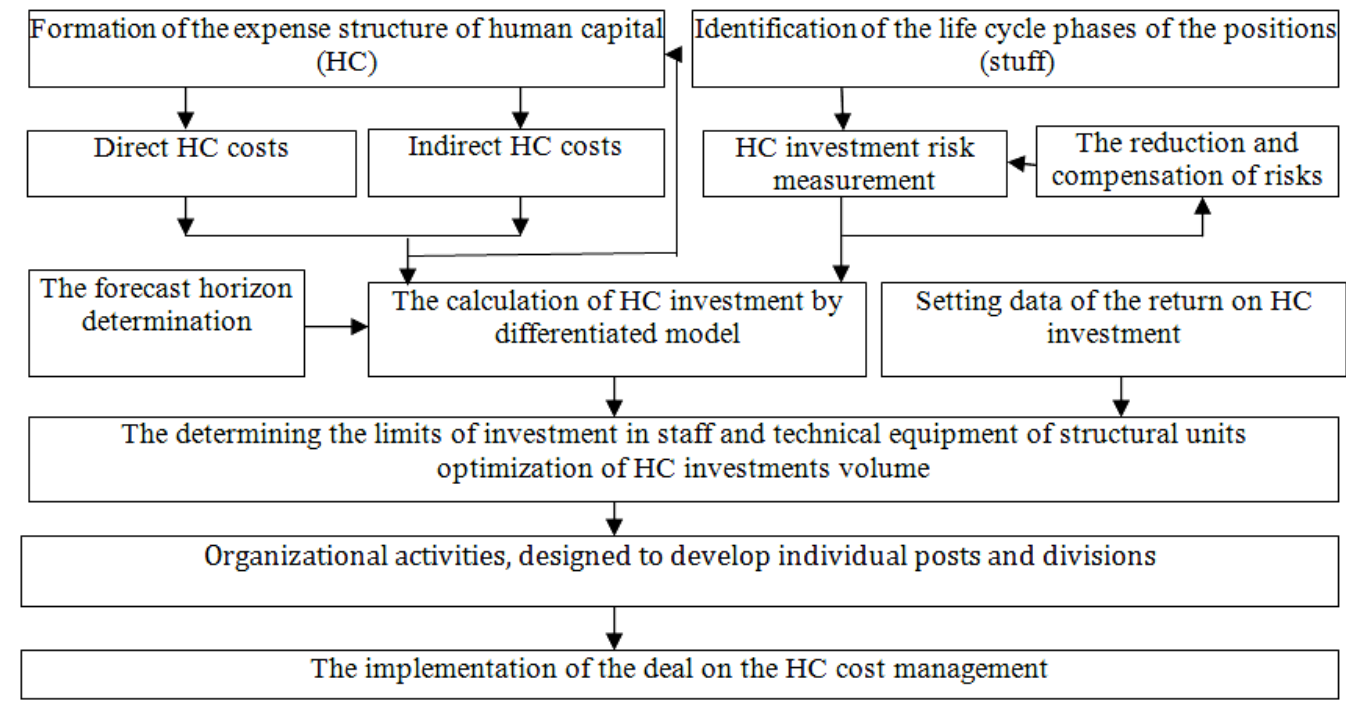

Figure 1. Sequence proposed assessment methodology and cost management of human capital

\section{Results}

In accordance with the microeconomic approach, investment in human headband allow for its expanded reproduction. The proposed technique involves structuring costs in the formation and development of human 
capital. Testing of methods for project materials reorganization of the management of LLC "Medical Centre" to structure the cost in human capital, which are listed in Table 1.

Table 1. Cost structure in the functioning and development of human capital on the draft reorganization LLC "Medical Centre" in 2013

\begin{tabular}{llll}
\hline $\begin{array}{l}\text { Expenses of operation and development of } \\
\text { human capital }\end{array}$ & $\begin{array}{l}\text { Amount } \\
\text { rub.) }\end{array}$ & $\begin{array}{l}\text { (thous. } \\
\text { expenses }\end{array}$ & $\begin{array}{l}\text { of } \\
\text { eferentage of total } \\
\text { costs }(\%)\end{array}$ \\
\hline 1. Salaries & 47732 & Direct & 14,6 \\
2. Insurance contributions & 10735 & Direct & 3,3 \\
3. Compensation and benefits & 16281 & Direct & 5,0 \\
4. Allowances and bonuses & 28863 & Direct & 8,8 \\
5. Professional Development & 6068 & Direct & 1,9 \\
6. Refresher & 4441 & Direct & 1,4 \\
7. Termination benefits & 9253 & Direct & 2,8 \\
8. Pensions & 14064 & Direct & 4,3 \\
9. Expenditure on hiring and firing & 4958 & Indirect & 1,5 \\
10. Rental and maintenance of premises & 48914 & Indirect & 15,0 \\
11. Equipment and facilities & 96571 & Indirect & 29,6 \\
12. Travel Expenses & 9176 & Indirect & 2,8 \\
13. Hospitality & 16058 & Indirect & 4,9 \\
14. Contents of official vehicles & 4292 & Indirect & 1,3 \\
15. Electricity & 10362 & Indirect & 3,2 \\
16. Total direct costs & 135954 & Direct & 41,7 \\
17. Total indirect costs & 190331 & Indirect & 58,3 \\
18. The ratio of direct and indirect costs & 1 rub. of direct expenses-1,4 rub. of indirect expenses \\
\hline
\end{tabular}

\subsection{The Modelling Investment in Human Capital Operation, Taking into Account Different Degrees of Riskiness}

In the proposed method based on the use of the cost approach to assess the magnitude of accumulated investment in the work place or position in relation to the administrative staff of Ltd. "Medical Centre" models have been developed for evaluating investments in human capital. Investment in human capital, as well as any other object of investments with the risk of non-repayment of the invested funds, non-receipt of the planned profit, which requires an assessment of their riskiness and relates risk to the planned return.

We proceeded from the assumption that used within the financial management approach to integrate the average financial risk through the mechanism of discounting investment is insufficient to adequately assess the riskiness of investing in staff. Studies have shown that investments in human capital are more risky in nature, rather than investments in fixed or working capital, and there are no tools available insurance and reinsurance risks, such as when investing in equipment, buildings and structures, securities.

If we analyse the change in the riskiness of investing in human capital for the entire period of the employees, we can distinguish four intervals riskiness (Figure 2):

a) The first 5-7 years of service-low, slowly increasing of riskiness of the investment, as the absolute value of the investments is small enough, verifies the compliance officer of the employee required quality, reliability and prospects as an investment object.

b) The next 7-10 years of service the riskiness of the investment increases significantly, as this period is connected with the active promotion of an employee, the expenditure of funds for training and retraining, intensive financial stimulation of his work. This period is characterized by moderate riskiness of investment in human capital.

c) The following 10 years of service are characterized by a peak career employee when it reaches the maximum level of competence and efficiency in work and management must make significant efforts for the material and moral incentives to save valuable expert in the enterprise. Nevertheless, the riskiness of investment in human capital will be the highest in this period since the majority of workers relates to the change of career jobs. This 
period corresponds to the high risks of investment in staff.

d) The following 10-13 years of service before retirement age are characterized by a gradual decrease in the riskiness of investing in staff. This is due to the reduction in the absolute volume of investment (in particular, training, promotion and motivation) to give the bulk of the impact of all previous investments. This period corresponds to decreasing the riskiness of investing.

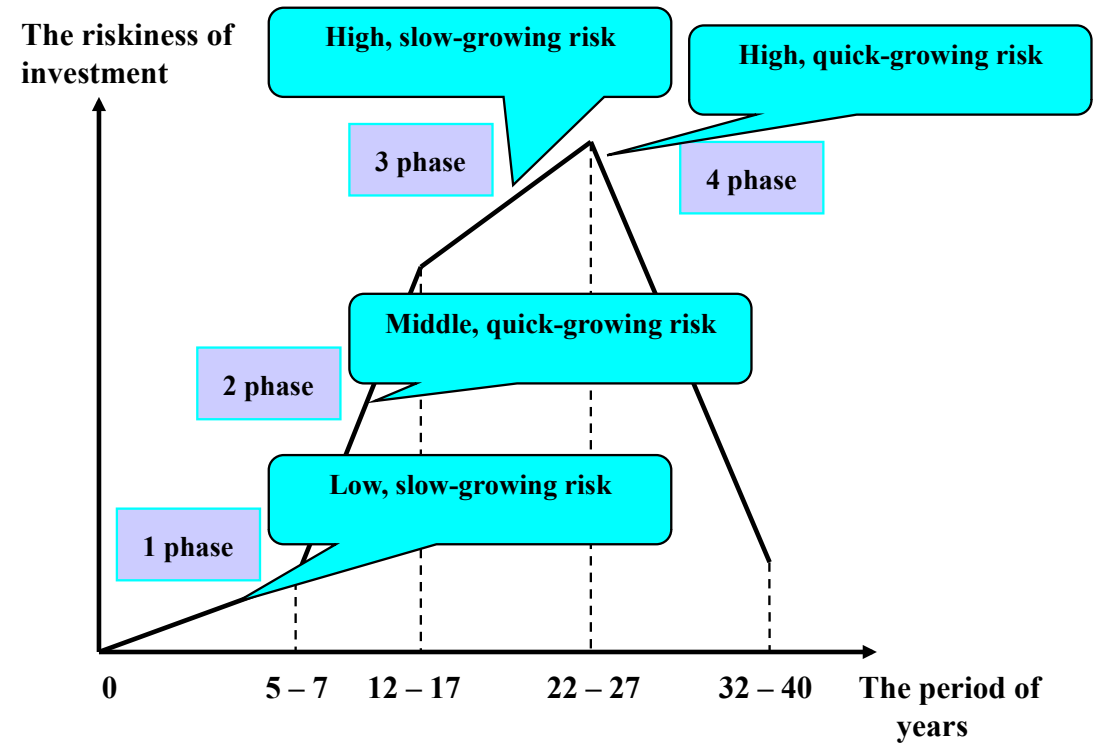

Figure 2. The dynamics of the riskiness of human capital investment

Obviously, when planning and accounting efficiency of investments in staff, which is located in different areas of riskiness suitable differentiation in predicting the amount of risk in the process of determining the required amount of capital. In particular, for a period of low riskiness of the calculation of investment in employee (position) in the framework of the reorganization of the administrative apparatus, LLC "Medical Center" was used the following mathematical model taking into account the cautious investment policy in relation to the object of investment:

$$
U_{\min }=\sum_{i=1}^{\mathrm{n}} O_{r i} \cdot\left(1+C_{\mathrm{ni}}+C_{\mathrm{ci}}+\mathrm{D}_{\mathrm{ci}}+\mathrm{D}_{\mathrm{ni}}\right) \cdot\left(1+D_{\mathrm{ki}}\right) \cdot\left(1+R_{h} B_{\mathrm{i}}\right)^{i}
$$

Ori-annual salary in the i year;

Sni-fixed share premium deductions from salary;

CCI-a fixed proportion of the salary value of indexing;

Dci-the percentage of insurance deductions from salary;

Dni-the share of social benefits and privileges of the salary;

Dki-the share of indirect costs per unit of direct costs in staff;

Bi-the discount factor;

Rh-correction factor taking into account the additional risks.

For periods of moderate to high risks of investment in staff suitable model that allows to consider aggressive investment policy:

$$
U_{\max }=\sum_{i=1}^{\mathrm{n}} O_{r i} \cdot \mathrm{J}_{\mathrm{ni}}^{\mathrm{i}} \mathrm{J}_{\mathrm{ci}}^{\mathrm{i}} \cdot\left(1+\mathrm{D}_{\mathrm{ci}}\right) \cdot\left(1+\mathrm{D}_{\mathrm{ni}}\right) \cdot\left(1+D_{\mathrm{ki}}\right) \cdot\left(1+R_{h} B_{\mathrm{i}}\right)^{i}
$$

Jni-index of bonuses in the i-th year;

Jci-indexation coefficient in the i-th year;

For a period of decreasing of the investing riskiness, a mathematical model which allows, on our opinion, to take 
into account a balanced investment policy:

$$
U_{\text {mid }}=\sum_{i=1}^{\mathrm{n}} O_{r i} \cdot \mathrm{J}_{\mathrm{ni}} \cdot \mathrm{J}_{\mathrm{ci}} \cdot\left(1+\mathrm{D}_{\mathrm{ci}}\right) \cdot\left(1+\mathrm{D}_{\mathrm{ni}}\right) \cdot\left(1+D_{\mathrm{ki}}\right) \cdot\left(1+R_{h} B_{\mathrm{i}}\right)^{i}
$$

The above models provide an estimate of the necessary investment in the operation and development of human capital, differentiated according to the projected investment period and the degree of riskiness of the life cycle phases of personnel occupying them.

\subsection{Optimization of Investment in Human Capital Development}

The proposed models were used to evaluate investments in human capital a number of management positions during the reorganization of the management of LLC "Medical Center", which led to the conclusion substantial underfunding of human capital development, especially in terms of technical equipment jobs of managers and specialists. The evaluation results are shown in Table 2.

Table 2. The calculation of the optimal rate of investment in leadership positions, LLC "Medical Center" for the period from 2014 to 2016 years

\begin{tabular}{|c|c|c|c|c|c|c|c|c|c|c|c|c|}
\hline \multirow[b]{2}{*}{ Position } & \multirow[b]{2}{*}{ Model } & \multicolumn{10}{|c|}{ Parameters of the model for investments evaluation } & \multirow[b]{2}{*}{$\begin{array}{l}\text { The amount of } \\
\text { investments } \\
\text { thous. rub }\end{array}$} \\
\hline & & $\begin{array}{l}\text { Ori } \\
\text { thous. } \\
\text { rub }\end{array}$ & Cni & Cci & Jni & Jci & Dci & Dni & Dki & $\mathrm{Bi}$ & $\mathrm{R}_{\mathrm{h}}$ & \\
\hline $\begin{array}{l}\text { 1. Development } \\
\text { Director }\end{array}$ & Umid & 564 & - & - & 1,52 & 1,16 & 0,11 & 0,12 & 1,23 & 0,08 & 1,17 & 9918 \\
\hline $\begin{array}{l}\text { 2. Head of } \\
\text { Personnel Training }\end{array}$ & Umid & 396 & - & - & 1,34 & 1,21 & 0,09 & 0,19 & 1,28 & 0,08 & 1,22 & 6883 \\
\hline $\begin{array}{l}\text { 3. Head of } \\
\text { Methodological } \\
\text { Department }\end{array}$ & Umin & 324 & 0,26 & 0,14 & - & - & 0,11 & 0,13 & 1,19 & 0,08 & 1,13 & 4161 \\
\hline $\begin{array}{l}\text { 4. Head of } \\
\text { residency }\end{array}$ & Umid & 432 & - & - & 1,38 & 1,23 & 0,12 & 0,22 & 1,32 & 0,08 & 1,25 & 8464 \\
\hline $\begin{array}{l}5 . \quad \text { Chief } \\
\text { ophthalmologist }\end{array}$ & Umax & 636 & - & - & 1,62 & 1,25 & 0,08 & 0,1 & 1,44 & 0,08 & 1,38 & 13860 \\
\hline 6. Chief Therapist & Umax & 672 & - & - & 1,58 & 1,19 & 0,09 & 0,13 & 1,36 & 0,08 & 1,46 & 13798 \\
\hline 7. Surgeon & Umax & 738 & - & - & 1,64 & 1,23 & 0,09 & 0,11 & 1,54 & 0,08 & 1,43 & 17112 \\
\hline
\end{tabular}

In general, as shown in Table 2, the most significant investment for the period from 2104 to 2016 is advisable to invest in major Professionals LLC "Medical Centre" heading priorities for its activities. These positions are held by experienced, highly qualified, prospective employees, not yet reached the peak of the career and highly demanded in the labour market. Therefore, the risks of investing in them would be the maximum that determined the choice of the appropriate model for calculating the investment. The most important areas of investment are financial incentives, training and improvement of technical equipment of their work. Investments in executive leaders will have less essential character, because these employees have long been working in the organization, passed the peak of career, less significant for the main activity of "Medical Centre" and less demand on the labour market. Therefore, to assess the investment was chosen Umid model. An exception is the chief of methodical department. These charges are temporarily takes a young employee, just 1.5 years working in the organization, whose personal and business prospects are just estimated, it determines the choice of Umin model.

\section{Discussion}

Using the above optimization models of investment in human capital operation enabled a retrospective analysis of the investment policy, LLC "Medical Centre" in the development of management personnel in 2011-2013 years. Optimization of calculations of investments in senior positions in relation to the actual amount of funding showed significant differences between the actual and modelled investment performance, which demonstrated the existence of a stable trend of underfunding. The calculation results are shown in Figure 3. 
According to them, the maximum amount of underfunding-58.7\%, accounted for the major specialists who guide the main directions of the professional activity of "Medical Centre" and to maximize the impact on organizational performance. $44.7 \%$ of underfunded main specialists relates to indirect costs associated with professional development and technical equipment jobs.

The lack of effective investment policy with respect to the operation and development of human capital according to our estimates leads to a substantial loss of profit by which the organization suffers for the period under review.

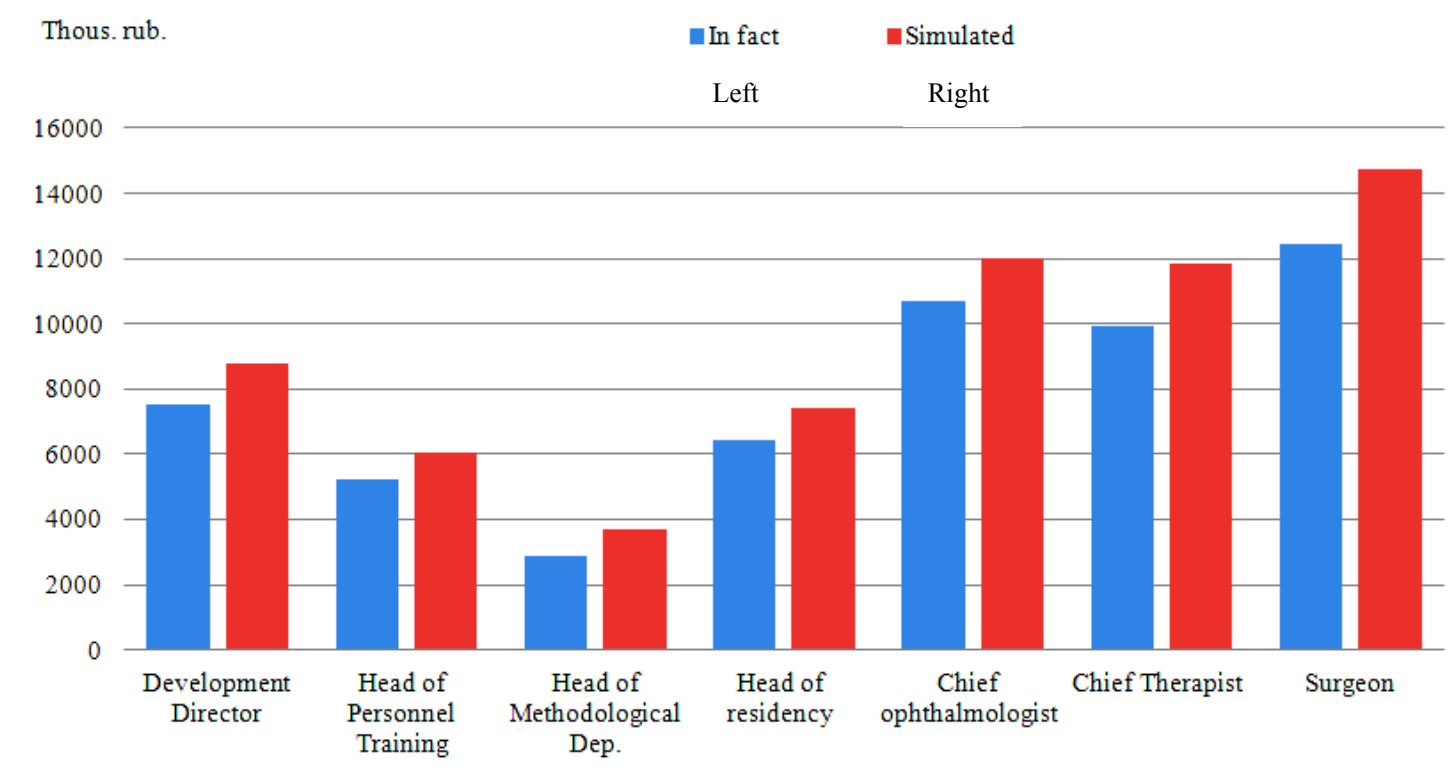

Figure 3. Retrospective analysis of the volume of investment in leadership positions, LLC "Medical Center" for 2011-2013

Study the nature of dependence between additional investment in human capital management apparatus LLC "Medical Centre" and the dynamics of return on net assets of the organization has allowed to develop a regression model of economic efficiency of investment in the development of additional management personnel, which is priced based on the size of the effect of forgone underfunding.

$$
E_{s}=0.35 * E_{c} * t^{2}-0.73 * E_{c} * t+1.16 * E_{c}
$$

$E_{S}$-the value of omitted effect on investment in human capital;

$E_{C}$-the amount of annual underfunding;

$t$-time interval estimates of omitted effect.

The omitted effect of payment is shown in Table 3.

Table 3. Evaluation of omitted economic effect as a result of underfunding of investment in human capital of "Medical Centre"

\begin{tabular}{lll}
\hline Year of loosing of economic effects & Volume of underfunding investment thous. rub & Omitted effect thous. rub \\
\hline 2011 & 2591 & 2021 \\
2012 & 3074 & 3381 \\
2013 & 3673 & 7788 \\
Total: & 9338 & 13189 \\
\hline
\end{tabular}

As a result of using the proposed methodology for assessing the human capital investment development in the 
implementation of the reorganization of the Project Management Co., Ltd. "Medical Centre" ways of improving the investment policy for management personnel have been formulated, the main ones are the following:

1) It is advisable to create a special structural unit acting as the valuation of human capital on the basis of recommended optimization models, track its dynamics, monitoring of factors influencing the efficiency of human capital, develop measures to improve the personnel and investment policies of the organization;

2) Personnel decisions on hiring and firing of leading specialists and managers should take the form of development of investment projects, involving evaluation of the optimal volume of investment in the foreseeable planning horizon forecasting, cost-effectiveness and assessment of investment risk that will draw conclusions about the investment attractiveness of the project;

3) Determination of the optimal amount of investment in human capital, it is advisable to make reference to the stage of the life cycle management position or stage of career development occupies its employee, which allows more accurate to consider the investment risks and plan the nature of investment policy in relation to this position;

4) Requires quarterly monitoring of the structure and the volume of investment in human capital of LLC "Medical Centre" for optimization, evaluation of volumes and directions of underfunding, loss of profit organization to develop appropriate investment and organizational decisions;

5) Financial Service Ltd. "Medical Centre" should set limits quarterly investment in staff and technological equipment structural units based on anticipated performance of their economic efficiency, taking into account investment risks, for this is expedient changes to the board and financial reports, providing them on volume figures investment in human capital and profitability.

Serious and still unresolved problem is the prediction and evaluation of the individual contribution of a particular employee in integrated financial performance of the unit or the entire company. Existing KPI-system performance assessment of employees and departments are mainly based on expert techniques and, in our opinion, do not allow a satisfactory objective and accurate assessment of the effectiveness of the individual objects of investment in human capital. It is therefore advisable to develop a unified system of indicators to assess the effectiveness of investments in human capital, which, in our opinion, should be based on a system of financial performance of investment projects on the UNIDO methodology.

\section{Conclusion}

In general, the proposed method enables the synthesis of the cost approach to assess the cumulative investment in managerial position and expert riskiness assessment method of investing in different stages of life cycle prediction of optimal investment and yields.

This technique allows you to structure expenses in the operation and development of human capital, identify risky investment stage, depending on the life cycle phase or post an employee's career, to choose the optimal investment policy, taking into account the level of riskiness of investment, optimize investment needed in the development of human capital, a retrospective analysis of investment policy for its rationality, to calculate limits investment in staff and technological equipment for each structural unit on the basis of set parameters of efficiency of investments, to develop organizational action plan on development of human capital, which ensures reliable and methodological basis for the management of its cost.

\section{References}

Becker, G. S., Murphy, K. M., \& Tamura, R. F. (1990). Human Capital, Fertility, and Economic Growth. Cambridge: NBER. Working Paper No. 3414. http://dx.doi.org/10.3386/w3414

Boudreau, J. W., \& Ramstad, P. M. (1997). Measuring intellectual capital: Learning from financial history. Human Resource Management, 36, 343-356. http://dx.doi.org/10.1002/(SICI)1099-050X(199723)36:3< 343::AID-HRM6>3.0.CO;2-W

Brooking, A. (1996). Intellectual Capital: Core Asset for the Third Millennium. London: Caspian Publishing.

Edvinsson, L., \& Malone, M. S. (1997). Intellectual Capital: Realizing your Company's True Value by Finding Its Hidden Roots. New York: Harper Business.

Gambardella, A., Panico, C., \& Valentini, G. (2013, November 23). Strategic incentives to human capital. Strategic Management Journal. http://dx.doi.org/10.1002/smj.2200

Hayton, J. C. (2005, March). Competing in the new economy: The effect of intellectual capital on corporate entrepreneurship in high-technology new ventures. $R \& D$ Management, 35(2), 137-155. http://dx.doi.org/10. 
1111/j.1467-9310.2005.00379.x

Hsu, L. C., \& Wang, C. H. (2012, June). Clarifying the Effect of Intellectual Capital on Performance: The Mediating Role of Dynamic Capability. British Journal of Management, 23(2), 179-205. http://dx.doi.org/ 10.1111/j.1467-8551.2010.00718.x

Kendrick, J.W. (1976). The Formation and Stocks of Total Capital. Cambridge: NBER.

Kiernan, M. J. (1997, June). Get Innovative or Get Dead! Building Competitive Companies for the 21st Century. London: Random House Business Books.

Miller, S. H. (2000). Managing Editor. Intellectual capital for all. Competitive Intelligence Review, 11(4), 3. http://dx.doi.org/10.1002/1520-6386(200034)11:4<3::AID-CIR2>3.0.CO;2-C

Mincer, J. (1994, August). The Production of Human Capital and the Lifecycle of Earnings: Variations on a Theme. Working Paper of the NBER, (4838).

Mulligan, C. B., \& Sala-i-Martin, X. (1995, February). Measuring Aggregate Human Capital. Working Paper of the NBER, (5016).

Roos, J., Pike, S., \& Fernstrom, L. (2006, February). Managing Intellectual Capital in Practice. London: Routledge.

Schultz, T. (1970). Investment in Human Capital. The Role of Education and of Research. American Journal of Agricultural Economics, 53(4).

Shaw, J. D., Park, T. Y., \& Kim, E. (2013, May). A resource-based perspective on human capital losses, HRM investments, and organizational performance. Strategic Management Journal, 34(5), 572-589. http://dx.doi.org/10.1002/smj.2025

Stewart, T. A. (1998). Intellectual Capital-The New Wealth of Organizations. London: Nicholas Brealey Publishing.

Wright, P. M., \& McMahan, G. C. (2011, April). Exploring human capital: Putting 'human' back into strategic human resource management. Human Resource Management Journal, 21(2), 93-104. http://dx.doi.org/10. $1111 / \mathrm{j} .1748-8583.2010 .00165 . \mathrm{x}$

\section{Copyrights}

Copyright for this article is retained by the author(s), with first publication rights granted to the journal.

This is an open-access article distributed under the terms and conditions of the Creative Commons Attribution license (http://creativecommons.org/licenses/by/3.0/). 